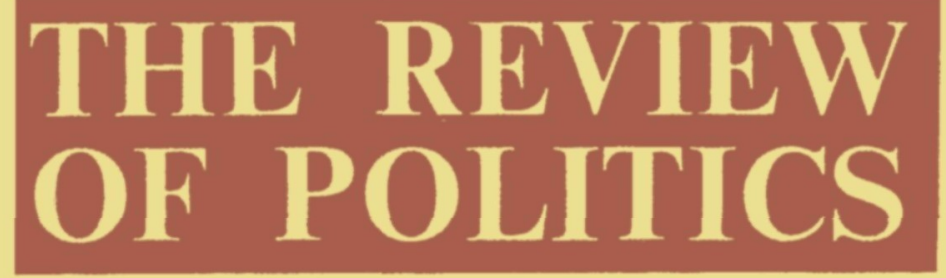

Mill on Liberty and Morality

Harry M. Clor

Mill's Liberal Feminism

Jennifer Ring

Taking Dworkin Seriously

Stanley C. Brubaker

Equal Protection and Edueation in Germany Hans Weiler

Concept of Political Community in Aristotle Bernard Yack

$$
\text { Vol. } 47 \text { - January, } 1985 \text { - No. } 1
$$

University of Notre Dame

Notre Dame, Indiana 


\title{
THE REVIEW OF PQLITICS
}

\author{
Editor \\ DONALD P. KOMMERS \\ Managing Editor \\ DENNIS WM MORAN
}

Associate Editors

Philip Gleason

Thomas Striteh

Thomas Werge

\section{Book Review Editor}

Walter Niegorski

Former Editors

Waldemar Gurian

Thomas Striteh

M. A. Fitzsimons Frederick J. Crosson

\section{Editorial Advisory Board}

Henry J. Abraham

University of Virginia

Charles W. Anderson

University of

Wisconsin-Madison

Shlomo Avineri

Hebrew University of Jerusalem

Walter Dean Burnham Massachusetts Institute of Technology

Robert F. Byrnes Indiana University

Eugeen De Jonghe Catholic UniversityLouvain

Ernest L. Fortin Beston College
Penny T. Gill Mount Holyoke College

Gerald Garvey

Princeton

University

Arend Lijphart

University of Call.

fornia-San Diego

Alasdair MaeIntyre

Vanderbilt

University

Harvey C. Mansfield, Jr. Harvard University

John R. Sehmidhauser

University of Sowthern

California

Glenn Tinder

University of

Massachusetts-Boston

The Review of Politics, without neglecting the analysis of institutions and techniques, is primarily interested in the philosophical and historical approach to political realities.

The articles in The Review of Politics are indexed in the International Index to Periodicals and the Index of Catholic Periodicals and abstracted in the International Political Science Abstracts. They are abstracted and indexed in ABC POL. SCI. and HISTORICAL ABSTRACTS and Social Sciences Index.

Copyright 1985 by the University of Notre Dame. Published quarterly at the University of Notre Dame. Issued each January, April, July and October. Entered as second-class matter April 1, 1939, at the post office at Notre Dame, Indiana, under act of March 2, 1879. Subscriptions: Institutional, $\mathbf{\$ 2 0 . 0 0}$ the year in the United States (Individual. \$15.00); foreign \$17; single copies, \$5.00. 


\title{
THE REVIEW OF POLITICS
}

\section{Volume XLVII \\ 1985}

\author{
Editor: Donald P. Kommers \\ Managing Editor: Dennis Wm Moran \\ Issued each January, April, July and October
}

\begin{abstract}
Opinions expressed in the articles printed in The Review of Politics are those of the authors alone and are not necessarily opinions held by the editors.
\end{abstract}

Subscriptions: Institutional, $\$ 20.00$ the year in the United States (Individual, $\$ 15.00$ ); foreign, $\$ 17.00$; single copies, $\$ 5.00$.

Entered as second-class matter, April 1, 1939, at the Post Office at Notre Dame, Indiana, under the act of March 3, 1879. 


\section{Index of Articles, 1985}

Wayne H. Ambler, Aristotle's Understanding of the Naturalness of the City . . . 163

M. E. Brint, Jean-Jacques Rousseau and Benjamin Constant: A Dialoque of Freedom and Tyranny .............................. 323

Stanley C. Brubaker, Taking Dworkin Seriously ................ 45

Gregory Claeys, The Lion and the Unicorn, Patriotism, and Orwell's Politics . . 186

Harry M. Clor, Mill and Millians on Liberty and Moral Character. . . . . . . . 3

John W. Coffey, The Statesmanship of Harry S Truman............... 231

Fred R. Dallmayr, Pragmatics dnd Hermeneutics................. 411

Douglas J. Hoekstra, Presidential Power and Presidential Purpose . . . . . . . . 566

Donald P. Kommers, The Supreme Court and the Constitution: The Continuing

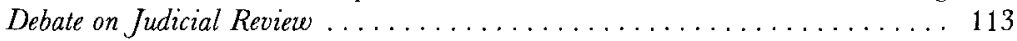

Jan Marejko, World Order or World Control?................. 588

Peter H. Merkl, Mapping the Temporal Universe of Party Governments . . . . . . . 483

Eugene F. Miller, The Icon of the American Republic: A Study in Political Symbolism .................................. 516

Grant B. Mindle, Machiavelli's Realism.................... 212

Elmer Plischke, The President's Image as Diplomat in Chief . . . . . . . . . . 544

Jennifer Ring, Mill's The Subjection of Women: The Methodological Limits of Liberal Feminism ........................... 27

Barry Schwartz, The Icon of the American Republic: A Study in Political Symbolism . . . . . . . . . . . . . . . . . . . . . . . . . . . . 516

Raguveer Singh, Causality, Meaning and Purpose in Politics............ 390

A. Anthony Smith, Kant's Political Philosophy: Rechtsstaat or Council Democ-

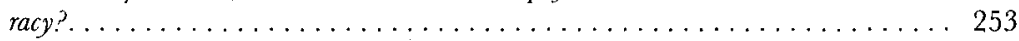

Brian T. Trainor, The Politics of Peace: The Role of the Political Covenant in Hobbes's Leviathan .

Hans Weiler, Equal Protection, Legitimacy, and the Legalization of Education: The Role of the Federal Constitutional Court in West Germany .......... 66

Joel D. Wolfe, A Defense of Participatory Democracy .............. . . 370

Bernard Yack, Community and Conflict in Aristotle's Political Philosophy. . . . . . 92

\section{Index of Book Reviews, 1985}

Allen, James Sloan, The Romance of Commerce and Culture Capitalism, Modernism, and the Chicago-Crusade for Cultural Reform (Steven D. Lavine) . . . . . 139

Aspinwall, Bernard, Portable Utopia, Glasgow and the United States, 1820-1920 (Vincent P. DeSantis)........................... 157

Banfield, Edward C., The Democratic Muse: Visual Arts and the Public Interest

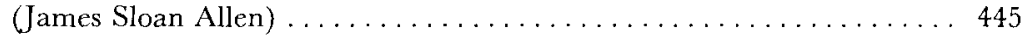

Blumenberg, Hans, The Legitimacy of the Modern Age (Frederick J. Crosson) 625 Borbet, David Vaughn, The Presidency of Lyndon B. Johnson (Robert E.

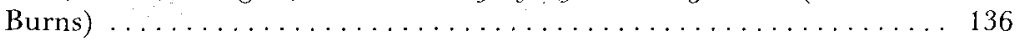

Braunthal, Gerard, The West German Social Democrats, 1969-1982: Profile of a Party in Power (Peter H. Merkl) . . . . . . . . . . . . . . . . . . . . . . 457 
Cohen, Bernard L., Before It's Too Late: A Scientist's Case for Nuclear Energy

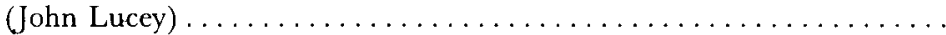

Cohen, Jean L., Class and Civil Society: The Limits of Marxian Critical Theory (Patrick Murray and Jean Schuler) ... . . . . . . . . . . . . . . . 142

Dent, N. J. H., The Moral Psychology of the Virtues (Alasdair MacIntyre) . . 436 Drell, Sidney D., Facing the Threat of Nuclear Weapons (Joseph M. Siracusa) 292 Dupre, Louis, Marx's Social Critique of Culture (R. Bruce Douglass) . . . . . 470 Elias, Julius A., Plato's Defense of Poetry (Janet E. Smith). . . . . . . . . . 473 Epstein, David F., The Political Theory of "The Federalist" (George W. Ca-

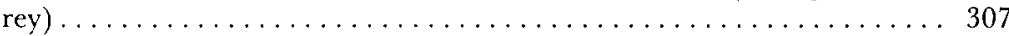

Felix, David, Marx as Politician (James M. Rhodes) . . . . . . . . . . . . . 146

Finnis, John, Fundamentals of Ethics (S. B. Drury) . . . . . . . . . . . . 432

Fishkin, James S., Justice, Equal Opportunity, and the Family (David Lewis

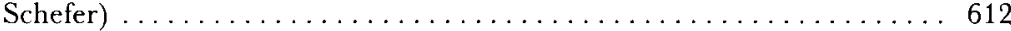

Furet, François, In the Workshop of History (André Goddu) . . . . . . . . 637

Garay, Ronald, Congressional Television: A Legislative History (Robert Schmuhl ) . . . . . . . . . . . . . . . . . . . . . . . . . . . . . . . . 448

Glover, Jonathan, What Sort of People Should There Be? (S. B. Drury) . . . . . 285

Harrington, Michael, The Politics at God's Funeral (Henry C. Johnson, Jr.). 282

Hinchman, Lewis P., Hegel's Critique of the Enlightenment (Steven B. Smith) 464

Hulliung, Mark, Citizen Machiavelli (Harvey C. Mansfield, Jr.) . . . . . . . . 298

James, Joseph B., The Ratification of the Fourteenth Amendment (David

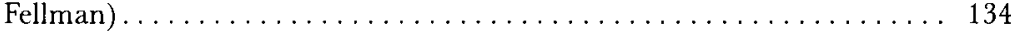

Jonas, Hans, The Imperative of Responsibility (Victor Ferkiss) . . . . . . . . 288

Kateb, George, Hannah Arendt: Politics, Conscience, Evil (Gordon J. Tolle) . . 309

Kertesz, Stephen D., Between Russia and the West: Hungary and the Illusion of Peacemaking 1945-1947 (Eugene Davidson). . . . . . . . . . . . . . . . . . 462

Klehr, Harvey, The Heyday of American Communism: The Depression Decade

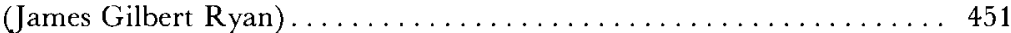

Lang, Gladys Engle, and Lang, Kurt, Politics and Television Re-Viewed (Robert Schmuhl) . . . . . . . . . . . . . . . . . . . . . . . 448

Liebman, Charles S., and Don-Yehiya, Eliezer, Religion and Politics in Israel (Jonathan S. Woocher) . . . . . . . . . . . . . . . . . . . 314

Light, Paul C., Vice-Presidential Power: Advice and Influence in the White House

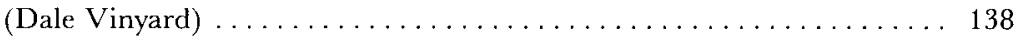

Logan, George M., The Meaning of More's "Utopia" (Thomas I. White). . 154

Mitias, Michael H., Moral Foundation of the State in Hegel's Philosophy of Right (Michael Allen Gillespie) . . . . . . . . . . . . . . . . . . . . . . . 468

Neuhaus, Richard John, The Naked Public Square: Religion and Democracy in

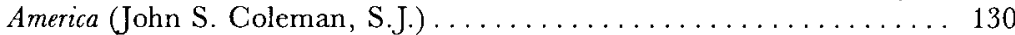

Newmyer, R. Kent, Supreme Court Justice Joseph Story: Statesman of the Old Republic (David Fellman) . . . . . . . . . . . . . . . . . . . . . . 628

Oakeshott, Michael, On History and Other Essays (Steven B. Smith) . . . . . 150

Polsby, Nelson W., Political Innovation in America: The Politics of Policy Initia-

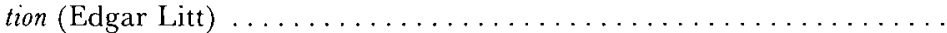


Power, Susan M., Before the Convention: Religion and the Founders Uohn A.

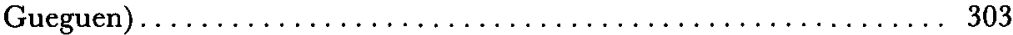

Pessen, Edward, The Log Cabin Myth: The Social Background of Presidents

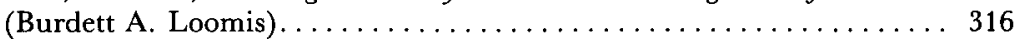

Ricci, David M., The Tragedy of Political Science: Politics, Scholarship, and De-

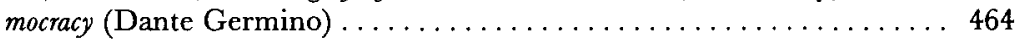

Riemer, Neal, The Future of the Democratic Revolution: Toward a More Prophetic Politics (Robert B. Thigpen) . . . . . . . . . . . . . . . . . . . . 441

Rosen, Stanley, Plato's Sophist (James L. Wiser) . . . . . . . . . . . 296

Schacht, Richard, Nietzsche (Nancy Love)................. 631

Schutte, Ofelia, Beyond Nihilism: Nietzsche Without Masks (Nancy Love). . . 631

Schwartz, Joel, The Sexual Politics of Jean-Jacques Rousseau (Penny A. Weiss) 300

Semmel, Bernard, John Stuart Mill and the Pursuit of Virtue (Harry M. Clor) 617

Smith, Bruce James, Politics and Remembrance: Republican Themes in Machiavelli, Burke, and Tocqueville ..................... 622

Spalding, Karen, Huarochiri: An Andean Society Under Inca and Spanish Rule (Fredrick B. Pike) . . . . . . . . . . . . . . . . . . . . . 454

Thaxon, Ralph, China Turned Rightside Up: Revolutionary Legitimacy in the Peasant World (Peter R. Moody, Jr.) . . . . . . . . . . . . . . . . . . . . . 459

Walasky, Paul W., 'And So We Come to Rome': The Political Perspective of St.

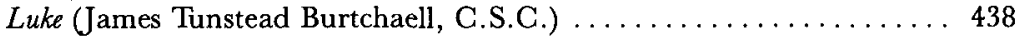

Ward, James F., Language, Form and Inquiry: Arthur F. Bentley's Philosophy of Social Science (William I. Buscemi) . . . . . . . . . . . . . . . . . . 294

Wildavsky, Aaron, The Nursing Father: Moses as a Political Leader (Joseph

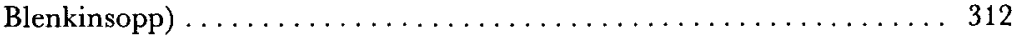

Wilson, Stephen G., Luke and the Law (James Tunstead Burtchaell, C.S.C.). 


\section{THE REVIEW OF POLITICS}

Published Quarterly by the University of Notre Dame, Indiana

Vol. 47

January 1985

No. 1

HARRY M. CLOR

Mill and Millians on Liberty and Moral Character........ 3

JENNIFER Ring

Mill's The Subjection of Women: The Methodological

Limits of Liberal Feminism

Stanley C. Brubaker

Taking Dworkin Seriously ................... 45

Hans Weiler

Equal Protection, Legitimacy, and the Legalization of

Education: The Role of the Federal Constitutional Court in

West Germany....................... 66

BERNARD YACK

Community and Conflict in Aristotle's Political Philosophy .. 92

Review Article:

Donald P. Kommers: The Supreme Court and the Constitution:

The Continuing Debate on Judicial Review . . . . . . . . . 113

Reviews:

John A. Coleman, S.J.: Religion in the Public Square ............... 130

Edgar Litt: Reform in the Public Square. . . . . . . . . . . . . . . . . . . 132

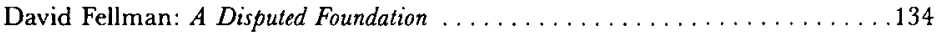

Robert E. Burns: The Presidency of the "Greal Society" ................136

Dale Vingard: The Emerging Vice-Presidency .....................

Steven D. Lavine: The Marketing of Culture . . . . . . . . . . . . . . . . 139

Patrick Murray and Jeanne Schuler: Marx's Failure as Theorist . . . . . . . . 142

James M. Rhodes: Marx as Nihilistic Superman . . . . . . . . . . . . . . 146

Steven B. Smith: The Character of Historical Understanding. . . . . . . . . . 150

Thomas I. White: The Maze of More's "Utopia" . . . . . . . . . . . . . . . . 154

Vincent P. DeSantis: Utopia for the New World .................. 157 


\section{Contributors to This Issue}

Harry M. Clor is Professor of Political Science in Kenyon College, Gambier, Ohio. Jennifer RING teaches political theory and feminism at Stanford in the Political Science Department and the Feminist Studies Program. Stanley C. Brubaker is Assistant Professor of Political Science in Colgate University. Hans Werler is Professor of Political Science in Stanford University. Bernard Yack is Assistant Professor of Politics in Princeton University. Donald P. Kommers is Professor of Government and Editor of The Review of Politics.

John A. Coleman, S.J., is Associate Professor of Religion and Society, the Graduate Theological Union, Berkeley. Edgar LitT teaches political science in the University of Connecticut. David Fellman is Vilas Professor of Political Science Emeritus in the University of Wisconsin, Madison. Dale Vinyard is Professor of Political Science in Wayne State University. Robert E. Burns is a member of the Department of History in the University of Notre Dame. Steven D. Lavine is Assistant Director for the Humanities in the Rockefeller Foundation. Patrick MUrRay and Jeanne Schuler are members of the philosophy faculty in Creighton University. JAMES M. Rhodes teaches political science in Marquette University. Steven B. Smith teaches political theory in Yale University. Thomas J. White is a member of the Philosophy and Religion faculty in Upsala College. Vincent P. DeSantis is Professor Emeritus in Notre Dame's Department of History.

\section{INSTRUCTIONS TO CONTRIBUTORS}

All manuscripts should be submitted in QUADRUPLICATE to The Review of Politics, Box B, Notre Dame, IN 46556. If the return of the manuscript is desired, a stamped, self-addressed envelope should be enclosed. All typewritten material should be double-spaced, including notes and quotations; photocopies of a good quality are acceptable. The Review follows the Chicago Manual of Style for standards of citation, punctuation and other editorial considerations. The normal length of manuscripts published is 25-30 pages. Longer manuscripts will be evaluated in light of the limited printing space available. Since manuscripts are evaluated anonymously they should not bear the author's name or institutional affiliation. Submissions should be sent with an ABSTRACT of 100-150 words. All correspondence regarding book reviews should be sent to Mr. Walter Nicgorski at the above address. 